\title{
Prevalence of Urinary Tract Infections and Associated Risk Factors among Pregnant Women in Enugu Metropolis, Nigeria
}

\author{
Ifeanyi Anthony Ezugwu ${ }^{1}$, Ruth Asikiya Afunwa ${ }^{2 *}$, Felix Chukwuebuka Onyia ${ }^{3}$, \\ Chidimma Ruth Chukwunwejim ${ }^{4}$, Ifunaya Maryann Offe ${ }^{1}$, Christie Oby Onyia ${ }^{1}$, \\ Marian Nneka Unachukwu1, Emmanuel Aniebonam Eze ${ }^{5}$
}

\footnotetext{
${ }^{1}$ Department of Biological Sciences, Godfrey Okoye University, Enugu State, Nigeria

${ }^{2}$ Department of Pharmaceutical Microbiology and Biotechnology, Faculty of Pharmaceutical Sciences, Chukwuemeka Odumegwu Ojukwu University, Igbariam, Nigeria

${ }^{3}$ Department of Pharmaceutical Microbiology and Biotechnology, Faculty of Pharmacy, Federal University of Oye Ekiti, Ekiti State, Nigeria

${ }^{4}$ Department of Pharmaceutical Microbiology and Biotechnology, Faculty of Pharmaceutical Sciences, Nnamdi Azikwe University, Agulu, Anambra State, Nigeria

${ }^{5}$ Department of Microbiologya, University of Nigeria, Nsukka, Enugu State, Nigeria

Email: *missruthus2000@yahoo.com, ^ra.afunwa@coou.edu.ng
}

How to cite this paper: Ezugwu, I.A. Afunwa, R.A., Onyia, F.C., Chukwunwejim, C.R., Offe, I.M., Onyia, C.O., Unachukwu, M.N. and Eze, E.A. (2021) Prevalence of Urinary Tract Infections and Associated Risk Factors among Pregnant Women in Enugu Metropolis, Nigeria. Journal of Biosciences and Medicines, 9, 156-171. https://doi.org/10.4236/jbm.2021.910014

Received: September 8, 2021

Accepted: October 24, 2021

Published: October 27, 2021

Copyright (๑) 2021 by author(s) and Scientific Research Publishing Inc. This work is licensed under the Creative Commons Attribution International License (CC BY 4.0).

http://creativecommons.org/licenses/by/4.0/

\section{(c) (i) Open Access}

\begin{abstract}
The prevalence of Urinary Tract Infections (UTI) among pregnant women was carried out in the Department of Obstetrics and Gynaecology of five (5) different hospitals in Enugu metropolis. Four hundred and eighty (480) pregnant women whose ages ranged from 20 - 40 years were recruited in this study using a well-designed questionnaire by random sampling technique. The subsidiary sample size included twenty (20) obstetricians working in these hospitals. Prevalence of UTI in the present study was affected by several factors namely; age, gestational age, socio-economic status, increased number of pregnancies or parity, untreated previous UTI history, diabetes, hypertension, and lack of personal hygiene. A total of 384 urine samples were collected from these pregnant women that attended antenatal care at the different hospitals for four (4) months. The urine samples were cultured and of the 384 urine samples analyzed, the following organisms were isolated; E. coli (89) (40.6\%), Staphylococcus aureus (62) (28.3\%), Klebsiella pneumoniae (36) (16.4\%), and Pseudomonas aeruginosa (18) (8.2\%). Others were Enterococcus sp. (8) (3.6\%), Enterobactersp. (4) (1.8\%), and Proteus sp. (2) (0.9\%) UTI was most prevalent among women of age category 36 - 40 years and the frequency was more in the third-trimester pregnancies. Early diagnosis and treatment of UTIs during pregnancy can ensure the safety of the mother and
\end{abstract}


the foetus. There is also a need for continuous health education during antenatal visits to boost physical and environmental hygiene.

\section{Keywords}

Pregnancy, UTI, Hospital, Bacteria, Urine

\section{Introduction}

Urinary tract infections (UTIs) are defined as inflammatory responses of the urothelium to bacterial invasion, which are usually associated with bacteriuria (bacteria in the urine) and pyuria (pus cells in the urine). UTIs are more common in women than in men partially due to the shorter and wider female urethra and its proximity to the anus [1]. The urinary tract includes the organs that collect and store urine and releases it from the body namely: the kidneys, ureters, bladder, and urethra. Bacteria associated with bacteriuria include Escherichia coli, Staphylococcus saprophyticus, Proteus mirabilis, Klebsiella pneumoniae, and Pseudomonas aeruginosa [1]. Urinary tract infection is one of the most frequently seen medical complications of pregnancy. Despite significant advances in managing urinary tract infections in pregnancy, its occurrence is still associated with adverse feto-maternal complications. Urinary Tract Infections in pregnancy remain a significant cause of maternal and perinatal morbidities, if untreated, the sequel is even grimmer. Routine screening for asymptomatic bacteriuria is advocated as well as prompt treatment of symptomatic and confirmed cases of suspected Urinary Tract infections [2].

Urinary tract infections (UTIs) are one of the most common medical complications of pregnancy [3]. It is estimated that one in three women of childbearing age will have a UTI [4]. Because of the normal physiologic changes induced by gestation, pregnant women are especially susceptible to these infections. UTIs are characterized by the presence of infectious agents in the genito-urinary tract that cannot be explained by contamination. These agents have the potential to invade the tissues of the urinary tract and adjacent structures. The microbiological profile is well known and pathogens such as Escherichia coli have been present in the vast majority of cases [5]. The infection may be limited to the growth of bacteria in the urine (which frequently don't produce symptoms) or it can result in several syndromes associated with an inflammatory response to the bacterial invasion. The term UTIs represents a wide variety of conditions, including asymptomatic forms of UTIs, urethritis, cystitis, acute pyelonephritis, and pyelonephritis with bacteremia or sepsis [6]. This study was done to determine the prevalence of urinary tract infections and associated risk factors among pregnant women in the Enugu metropolis.

\section{Methods}

Study Site: The study was carried out in the Department of Obstetrics and 
Gynaecology of the different hospitals in Enugu metropolis.

Sample Size: Four hundred and eighty pregnant women (480) whose ages ranged from 18 - 40 years were recruited in this study using a well-designed questionnaire by random sampling technique. The subsidiary sample size includes 20 (twenty) obstetricians working in these hospitals. Three hundred and eighty-four (384) urine samples of pregnant women with duly completed copies of questionnaires were collected.

Study Period: The study was conducted over a three-month period. From March to June, 2021.

Demographic Information: Socio-demographic data such as maternal age, parity, gestation age, social-economic status, marital status, previous ill health status etc. were collected using the questionnaires.

Sample Collection: Three hundred and eighty four (384) clean-catch midstream urine samples were collected from each pregnant woman into a sterilized screw capped container and labelled properly. Samples were moved to the laboratory for analysis within an hour of collection.

\section{Inclusion Criteria}

Pregnant women within ages 20 - 40 years who are apparently healthy and not on any special diets were enrolled in the study.

\section{Exclusion Criteria}

Pregnant women who are not within ages 20 - 40 years, pregnant women having renal disease or on any antibiotic therapy within 72 hours prior to encounter were excluded.

\section{Urine Culture}

Using a sterile wire loop, test bacteria on the cultured agar plates were introduced into $4 \mathrm{ml}$ of sterile nutrient broth to form a suspension and rotated for homogenization. The contents were allowed to set and the plates were incubated at $37^{\circ} \mathrm{C}$ for 24 hours. The turbidity of the suspension in nutrient broth was matched with the standard being the McFarland solution against a printed card or sheet of paper. The suspension containing test organisms was diluted with sterile saline prepared by adding $9 \mathrm{~g}$ of $\mathrm{NaCl}$ in $1000 \mathrm{mls}$ of distilled water and autoclaved. This was done to equal the turbidity of the test isolates with the McFarland solution [7].

\section{Antibiotic Sensitivity Test}

The urine samples were cultured using Antibiotic sensitivity of the isolates was determined by a suspension of a pure colony from each confirmed culture isolate was performed by using $0.85 \%$ sterile normal saline, and the suspension was adjusted at $0.5 \%$ MacFarland standard. Using a sterile cotton applicator stick, the suspension was distributed evenly on Muller-Hinton agar. Modified Kirby-Bauer disk diffusion technique was implemented for antibiotic susceptibility patterns using different antibiotics. Then, we applied those antibiotics on Mueller-Hinton agar plate and incubated them for $18-24$ hours at $37^{\circ} \mathrm{C}$. Inhibition zone diameters (IZDs) were measured. 


\section{Identification of Isolates}

Bacterial species were identified according to standard bacteriological methods by Cheesbrough 2005 [7].

\section{Preparation of Mcfarland Standard}

This was prepared according to Cockerill et al. [8]. A 1\% solution of Barium Chloride was prepared by adding $1 \mathrm{~g}$ of $\mathrm{BaCl}_{2}$ to $99 \mathrm{ml}$ of distilled water; $1 \%$ of solution of Sulphuric acid $\left(\mathrm{H}_{2} \mathrm{SO}_{4}\right)$ was prepared by adding $1 \mathrm{ml}$ of concentrated $\mathrm{H}_{2} \mathrm{SO}_{4}$ to $99 \mathrm{ml}$ of distilled water. A $0.5 \mathrm{McF}$ arland standard was then prepared by mixing $0.05 \mathrm{ml}$ of the prepared $\mathrm{BaCl}_{2}$ and $9.95 \mathrm{ml}$ of $\mathrm{H}_{2} \mathrm{SO}_{4}$.

\section{Standardization of Test Bacteria}

Using a sterile wire loop, test bacteria on the cultured agar plates were introduced into $4 \mathrm{ml}$ of sterile nutrient broth to form a suspension. In good light, the turbidity of the suspension in nutrient broth was matched with the standard being the McFarland solution against a printed card or sheet of paper. The suspension containing test organisms was diluted with sterile saline (prepared by adding $9.0 \mathrm{~g}$ of $\mathrm{NaCl}$ in $1000 \mathrm{mls}$ of distilled water and autoclaved) when necessary. This was done to equal the turbidity of the test isolates with the McFarland solution [7].

\section{Results}

The total copies of the questionnaire distributed were 480 but the study received a total of 330 duly completed copies of the questionnaire which constituted a response rate of 86 percent as shown in Figure 1 below. De Vaus [9] informs that a response rate of 80 percent and above is considered adequate. This implies that the response rate for the study was adequate to enable the researcher to perform the analyses.

Table 1 shows the Socio-Demographic Characteristics of Study Participants ranging from their ages, marital status, gestational age, number of pregnancies, level of Education and occupation.

\section{Age Bracket Respondents}

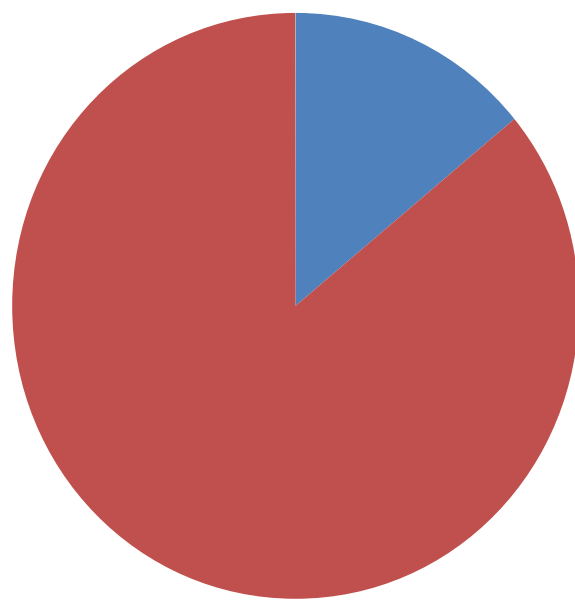

Not Responded $14 \%$

- Responded $86 \%$

Figure 1. Response rate for questionnaire. 
Table 1. Socio-demographic characteristics of study participants.

\begin{tabular}{|c|c|c|}
\hline Variable & Frequency (n) & Percentage (\%) \\
\hline \multicolumn{3}{|l|}{ Age (Years) } \\
\hline $20-25$ & 45 & 13.64 \\
\hline $26-30$ & 70 & 21.21 \\
\hline $31-35$ & 99 & 30.00 \\
\hline $36-40$ & 116 & 35.15 \\
\hline \multicolumn{3}{|l|}{ Marital Status } \\
\hline Single & 55 & 16.67 \\
\hline Married & 133 & 40.03 \\
\hline Separated & 65 & 19.70 \\
\hline Widow & 77 & 23.60 \\
\hline \multicolumn{3}{|l|}{ Gestational Age } \\
\hline $1^{\text {st }}$ Trimester & 83 & 25.15 \\
\hline $2^{\text {nd }}$ Trimester & 148 & 44.85 \\
\hline $3^{\text {rd }}$ Trimester & 99 & 30.00 \\
\hline \multicolumn{3}{|c|}{ Number of Pregnancies } \\
\hline $1-3$ & 128 & 38.79 \\
\hline $4-6$ & 108 & 32.73 \\
\hline 7 and above & 94 & 28.48 \\
\hline \multicolumn{3}{|l|}{ Level of Education } \\
\hline Primary & 77 & 23.34 \\
\hline Secondary & 84 & 25.45 \\
\hline Tertiary & 119 & 36.06 \\
\hline Uneducated & 50 & 15.15 \\
\hline \multicolumn{3}{|l|}{ Occupation } \\
\hline House wife & 81 & 24.55 \\
\hline Employed & 110 & 33.33 \\
\hline Self-employed & 139 & 42.12 \\
\hline
\end{tabular}

The majority of the respondents were between the ages of 36 and 40 years. Specifically, 45 respondents (13.64\%) were between 20 - 25 years, 70 respondents (21.21\%) were between 26 - 30 years, 99 respondents (30.0\%) were between 31 35 years while 116 respondents (35.15\%) were between 36 - 40 years.

\section{Marital Status of Respondents}

The marital status of respondents showed that 55 respondents (16.67\%) are single, 133 respondents $(40.03 \%)$ are married, and 65 respondents $(19.70 \%)$ are separated while 77 respondents representing $23.60 \%$ are widows. It was therefore shown that the majority of the respondents are married.

Gestational Age of Respondents 
The study showed that 83 respondents (16.67\%) are in the first trimester, 148 respondents representing $44.85 \%$ are in the 2 nd trimester while 99 respondents representing $30.0 \%$ are in the third trimester. It was therefore shown that the majority of the respondents are in their second trimester.

\section{Number of Pregnancies of Respondents}

The study showed that 128 respondents representing $38.79 \%$ have had 1 to 3 pregnancies, 108 respondents representing 32.73\% have had 4 to 6 pregnancies while 94 respondents representing $28.48 \%$ have had from 7 pregnancies and above. It was therefore shown that most of the respondents have had from 4 to 6 pregnancies.

\section{Level of Education}

On the level of education, 77 respondents representing $23.34 \%$ have a primary qualification, 84 respondents representing 25.45 percent have a secondary qualification, and 119 respondents representing 36.06 percent have tertiary qualification while 50 respondents representing $15.15 \%$ are uneducated.

\section{Occupation of Respondents}

The occupation of the respondents that took part in the research showed that 81 respondents representing $24.55 \%$ are housewives, 110 respondents representing $33.33 \%$ are employed while 139 respondents representing $42.12 \%$ are self-employed.

As shown in Table 2, prevalence of UTI was found to be higher among subjects of age category 36 - 40 years $(25.18 \%)$ positive cases of the total population studied. The incidence was also found to be higher among married women with a percentage of $31.56 \%$. Based on gestational age, UTI prevalence was higher among subjects in their third trimester with a percentage of $32.27 \%$. A high rate of UTI was found to be among women with a high number of pregnancies or high parity having a percentage of $31.56 \%$. The high prevalence rate was found among uneducated women and those with primary school certificates, and among unemployed, housewives, or low socio-economic subjects with percentages of $24.11 \%, 16.31 \%$, and $21.63 \%$ respectively.

\section{Prevalence of Urinary Tract Infections among Pregnant Women}

The total prevalence of Urinary Tract Infection (UTI) in pregnant women in the Enugu metropolis showed that out of the total of 384 subjects screened after urine samples were collected, $282(73 \%)$ cases of UTI were diagnosed among pregnant women in the hospitals under study while there were 102 (27\%) cases of Non-UTI among pregnant women (Figure 2).

From Figure 3, the prevalence of UTI in pregnant women to hypertension showed that the highest incidence of UTI was seen in women with high blood pressure representing $90.9 \%$ of the participants, the prevalence of UTI to untreated asymptomatic urinary tract infection showed a low incidence of UTI among 14 respondents representing $4.24 \%$ with no previous urinary tract infection while 316 respondents representing 95.76\% showed the highest UTI prevalence with records of previous urinary tract infection. UTI Prevalence in pregnant women to diabetes showed that the highest incidence was seen in women that are diabetic representing $75.76 \%$ of the participants while low UTI prevalence 
Table 2. Prevalence of urinary tract infections in relation to demographic distribution of the subjects and positive cases.

\begin{tabular}{|c|c|c|c|c|c|}
\hline Variable & Frequency (n) & Percentage (\%) & UTI+ & UTI- & UTI+ (\%) \\
\hline \multicolumn{6}{|l|}{ Age (Years) } \\
\hline $20-25$ & 45 & 13.64 & 13 & 27 & 3.90 \\
\hline $26-30$ & 70 & 21.21 & 25 & 46 & 7.45 \\
\hline $31-35$ & 99 & 30.00 & 50 & 41 & 15.25 \\
\hline $36-40$ & 116 & 35.15 & 83 & 45 & 25.18 \\
\hline \multicolumn{6}{|l|}{ Marital Status } \\
\hline Single & 55 & 16.67 & 30 & 25 & 10.64 \\
\hline Married & 133 & 40.03 & 89 & 44 & 31.56 \\
\hline Separated & 65 & 19.70 & 47 & 18 & 16.66 \\
\hline Widow & 77 & 23.60 & 13 & 64 & 4.60 \\
\hline \multicolumn{6}{|l|}{ Gestational Age } \\
\hline $1^{\text {st }}$ Trimester & 83 & 25.15 & 53 & 30 & 18.79 \\
\hline $2^{\text {nd }}$ Trimester & 148 & 44.85 & 78 & 70 & 27.66 \\
\hline $3^{\text {rd }}$ Trimester & 99 & 30.00 & 91 & 08 & 32.27 \\
\hline \multicolumn{6}{|c|}{ Number of Pregnancies } \\
\hline $1-3$ & 128 & 38.79 & 73 & 55 & 25.89 \\
\hline $4-6$ & 108 & 32.73 & 67 & 41 & 23.75 \\
\hline 7 and above & 94 & 28.48 & 89 & 05 & 31.56 \\
\hline \multicolumn{6}{|c|}{ Level of Education } \\
\hline Primary & 77 & 23.34 & 68 & 09 & 24.11 \\
\hline Secondary & 84 & 25.45 & 15 & 69 & 5.31 \\
\hline Tertiary & 119 & 36.06 & 23 & 96 & 8.15 \\
\hline Uneducated & 50 & 15.15 & 46 & 04 & 16.31 \\
\hline \multicolumn{6}{|l|}{ Occupation } \\
\hline House wife & 81 & 24.55 & 61 & 20 & 21.63 \\
\hline Employed & 110 & 33.33 & 42 & 68 & 14.89 \\
\hline Self employed & 139 & 42.12 & 49 & 90 & 17.37 \\
\hline
\end{tabular}

UTI+: Urinary tract infection positive cases; UTI-: Urinary tract infection negative cases.

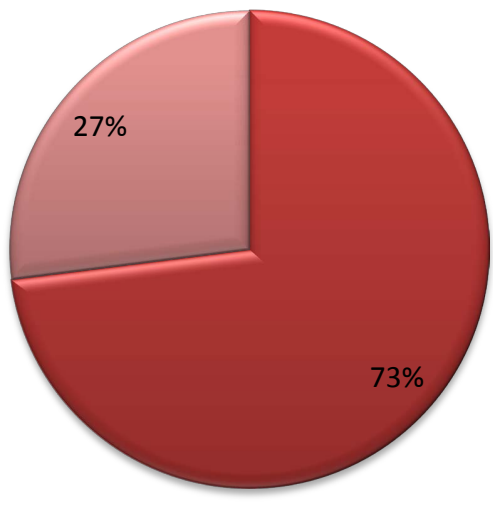

a UTI Positive 73\%

$\square$ UTI Negative $27 \%$

Figure 2. Prevalence of urinary tract infections among the pregnant women. 


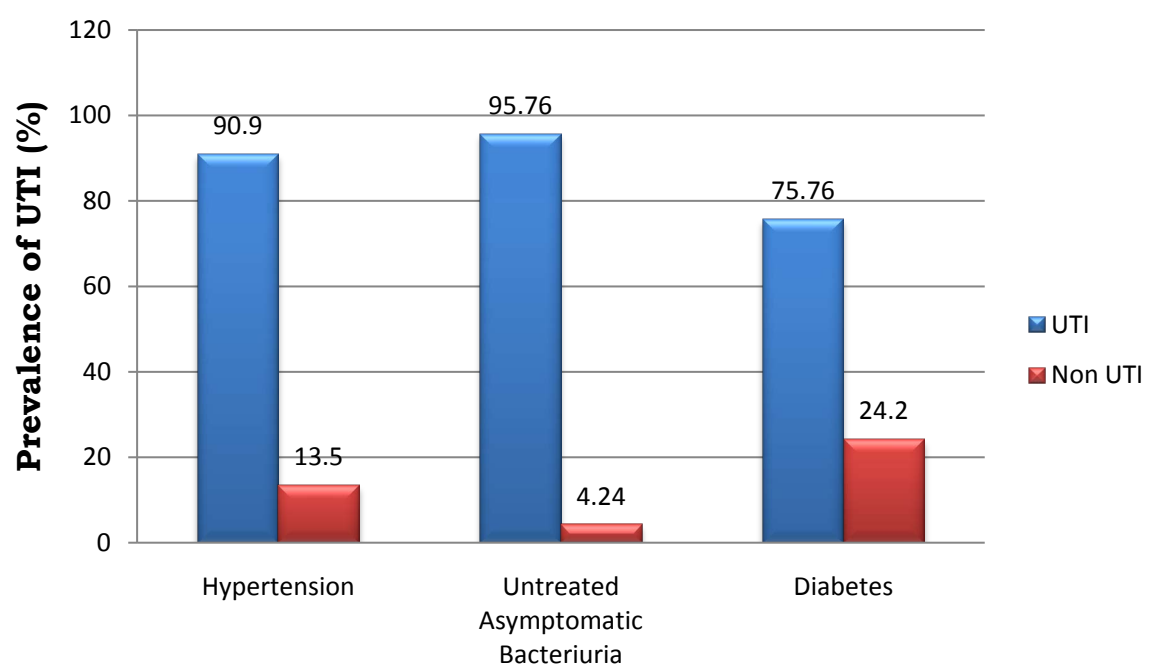

Figure 3. Urinary tract infections in relation to health risk factors. UTI urinary tract infection; Non UTI Non Urinary tract infection.

was found among non-diabetic pregnant women representing $24.24 \%$ of participants.

As shown in Table 3, in the socio-demographic characteristics of participant Doctors, 9 doctors out of 20 doctors were aged between 41 - 50 years of age (45\%) and 14 doctors were married (70\%), which showed that within their period of practice with pregnant women, they had different experiences on the prevalence of UTIs among pregnant women in Enugu metropolis, and also have experiences with the families on this prevalence. They responded based on their analysis of cases undergone during their period of practice.

As shown in Figure 4, the major prevalence risk factors are untreated asymptomatic bacteriuria, pre-existing diabetes, increased parity and low socioeconomic status with mean scores of 4.2, 4.0, 4.3 and 2.8 respectively. The least risk factor was low socioeconomic status while the highest risk factor was increased parity.

As shown in Table 4, the result of the percentage occurrence of bacteria isolates shows that Escherichia coli was the most prevalent organisms, 89 isolates (40.6\%), followed by Staphylococcus aureus, 62 isolates (28.3\%), Klebsiella pneumoniae with 36 isolates (16.4\%), Pseudomonas aeruginosa 18 isolates (8.2\%), Enterococcus spp. 8 isolates (3.6\%), Enterobacter spp. 4 isolates (1.8\%), and Proteus spp. as the least prevalent organisms, 2 isolates (0.9\%).

As shown in Table 5, Staphylococcus aureus was sensitive to Streptomycin, ciprofloxacin, gentamycin, ampicillin, cloxacillin, and rifampicin which made it the highest sensitive organism to these antibiotics, followed by Klebsiella pneumoniae which was sensitive to streptomycin, ciprofloxacin, gentamycin, ampicillin and augmentin. Pseudomonas aeruginosa was sensitive to ciprofloxacin, gentamycin, and augmentin. Enterococcus spp. was sensitive to ciprofloxacin and gentamycin. Enterobacter spp. was sensitive to streptomycin, ciprofloxacin and gentamycin, while E. coli was sensitive to streptomycin, ciprofloxacin, and rifampicin. 
Table 3. Socio-demographic characteristics of participant doctors.

\begin{tabular}{ccc}
\hline Parameters & Frequency (n) & Percentage (\%) \\
\hline Age (Years) & 4 & 20.0 \\
$30-40$ & 9 & 45.0 \\
$41-50$ & 7 & 35.0 \\
50 and above & & \\
Marital Status & 4 & 30.0 \\
Single & 14 & 70.0 \\
Married & 2 & 10.0 \\
Separated & & \\
\hline
\end{tabular}

Participant Doctors working in the hospitals where study was carried out responded based on their analysis of cases undergone during their period of practice.

Table 4. Percentage occurrence of isolated organisms from urine samples of patients.

\begin{tabular}{ccc}
\hline Organisms & No. of Occurrence & Percentage of Occurrence (\%) \\
\hline Escherichia coli & 89 & 40.6 \\
Staphylococcus aureus & 62 & 28.3 \\
Klebsiella pneumoniae & 36 & 16.4 \\
Pseudomonas aeruginosa & 18 & 8.2 \\
Enterococcus sp. & 8 & 3.6 \\
Enterobacter sp. & 4 & 1.8 \\
Proteus sp. & 2 & 0.9 \\
\hline
\end{tabular}

Table 5. Antibiotic susceptibility profile of bacteria isolates.

\begin{tabular}{ccccccccccccc}
\hline \multicolumn{10}{c}{ Antibiotics } \\
\hline Isolates & STR & CIP & GEN & AMP & ERY & AUG & FLO & SEP & LIN & CHL & RIF \\
\hline S. aureus & + & + & + & + & - & - & - & - & - & + & + \\
K. pneumoniae & + & + & + & + & - & + & - & - & - & - & - \\
P. aerogenousa & - & + & + & - & - & + & - & - & - & - & - \\
Enterococcus sp. & - & + & + & - & - & - & - & - & - & - & - \\
Enterobactersp. & + & + & + & - & - & - & - & - & - & - & - \\
E. coli & + & + & - & - & - & - & - & - & - & - & + \\
\hline
\end{tabular}

Key: STR = Streptomycin; CIP = Ciprofloxacin; GEN = Gentamycin; AMP = Ampicilin; ERY = Erythromycin; AUG = Augmentin; FLO = Floxacin; SEP = Septrin; LIN = Lincosin; CHL = Chloxacillin; RIF = Rifampicin. ( $+=$ Sensitive), $(-=$ Not Sensitive).

\section{Discussion}

Urinary Tract Infections (UTI) are the most common types of infections among pregnant women. They account for complications in pregnancy [10]. The present study showed that the UTI prevalence among pregnant women living in 


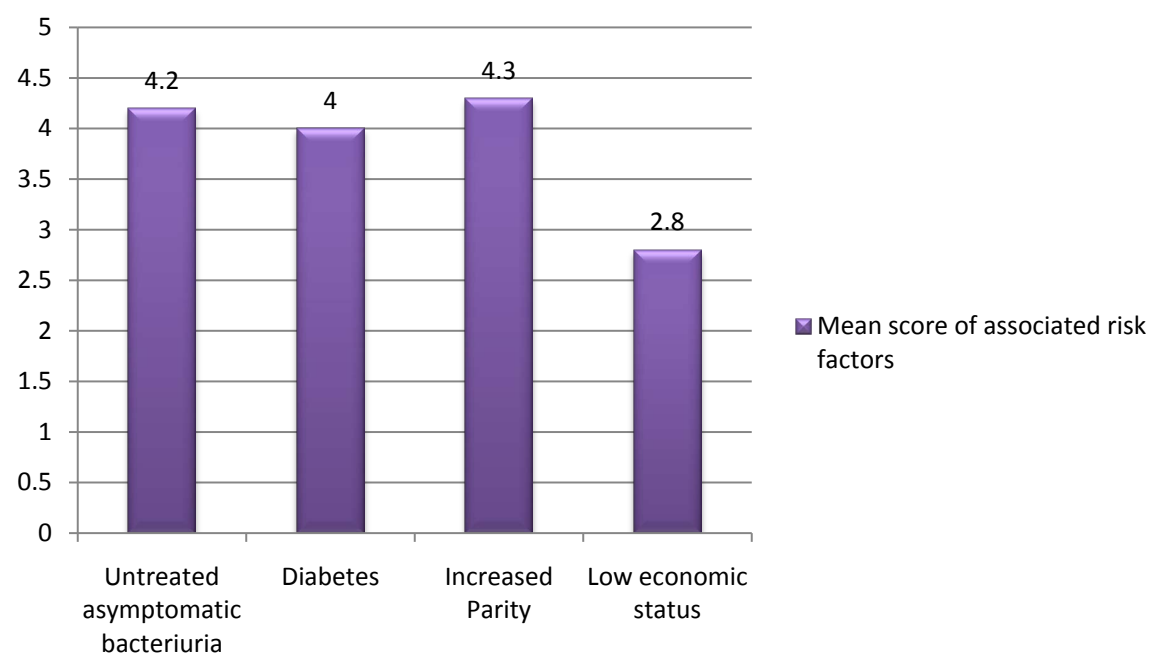

Figure 4. Major prevalence risk factors of urinary tract infections in pregnant women.

the Enugu metropolis (Eastern Nigeria) was $73 \%$ of 384 samples screened which is very high. The prevalent rate in this study was high compared to UTI prevalence recorded in previous studies showing pregnant women from other parts of the country recording $46.5 \%$ in Ebonyi, Eastern Nigeria [11], 35.5\% in Ilorin, North Central Nigeria [12], 31.6\% in Kano, Northern Nigeria [12], and 32.7\% in Benin, Southern Nigeria [13].

Prevalence of UTI in the present study, as in other studies, was affected by several factors namely, age, gestational age, socioeconomic status, increased in the number of pregnancies or parity, untreated previous UTI history, diabetes, hypertension, and lack of personal hygiene [14] [15]. Urinary Tract Infections were more prevalent among women of the age category of $36-40$ years. The finding differs from the research of Kawser et al. [16] and Nwachukwu et al. [17] which shows that UTI was more prevalent among women of $26-30$ years. The high incidence of UTI among women of ages 36 - 40 years may be due to a high rate of previous untreated UTI history, diabetes mellitus, high blood pressure, and lack of personal hygiene. These are known major risk factors of UTI prevalence. Among a studied population Stephen [14], Ranjan et al. [18] and Azami et al. [15] pointed out that previous UTI and diabetes can be increased risk factors for UTIs in pregnancy. Fasalu et al. [19] also stated that bacteriuria was more prevalent in multiparous women and women of advanced maternal age. A higher incidence of UTI was found to be among married women and occurred mostly in the third trimester [18] [20]. The increase in prevalence could be due to an increase in parity or a higher number of pregnancies.

The most frequently isolated bacteria were species of $E$. coli (40.6\%) followed by $S$. aureus $(28.3 \%) K$. pneumoniae (16.4\%) and P. aeruginosa (8.2\%). Others were Enterococcus sp. Enterobacter sp. and Proteus sp. Previous researches have shown that the most prevalently isolated bacteria were $E$. coli. S. aureus, and $K$. pneumoniae [15] [17] [21] [22] Presence of members of the Enterobacteriaceae family such as E. coli, Klebsiella, and Proteus suggests that infection was due to 
poor personal hygiene since these organisms are of fecal origin.

The antibiotic susceptibility test showed that the pathogens were highly sensitive to most of the antibiotics except streptomycin, ciprofloxacin, and gentamycin which recorded high resistance. This contradicts the report of Muhammed, [23] who recorded high sensitivity of pathogens to ciprofloxacin.

\section{Conclusion}

Early diagnosis and treatment of UTIs during pregnancy can ensure the safety of the mother and the foetus. There should be increased personal and environmental hygiene and there is a need to expand health services for the treatment of UTI in pregnant women. Infection prevention remains the best option and this can be achieved through health education during antenatal visits. Since UTIs occurred mostly in the third trimester of pregnancy, effective and proper medical care should be administered in the third trimester to checkmate the prevalence.

\section{Limitations}

- The level of education of some participants made it difficult and time-consuming in getting data from these participants.

- Counseling of participants prior to getting required data was time-consuming.

- Improper cleaning of the area prior to collection of the urine specimen or failing to collect the urine midstream will likely result in contamination of the specimen.

\section{Conflicts of Interest}

The authors declare no conflicts of interest regarding the publication of this paper.

\section{References}

[1] Afunwa, R., Nwokediuko, I. and Okolie, C.E. (2017) Asymptomatic Urinary Tract Infection in Pregnant Women. International Journal of Medical Sciences and Technology, 7, 28-34.

[2] Ajah, L.O., Agwu Onu, F., Olisaemeka Ezeonu, P., et al. (2015) Profile and Microbiological Isolates of Asymptomatic Bacteriuria among Pregnant Women in Abakaliki, Nigeria. Infection and Drug Resistance, 8, 231-235. https://doi.org/10.2147/IDR.S87052

[3] Mittal, P. and Wing, D.A. (2005) Urinary Tract Infections in Pregnancy. Clinical Perinatology, 32, 749-764. https://doi.org/10.1016/j.clp.2005.05.006

[4] Duarte, G., Marcolin, A.C., Quintana, S.M. and Cavalli, R.C. (2008) Urinary Tract Infection in Pregnancy. Revista Brasileira de Ginecologia e Obstetrícia, 30, 93-100. https://doi.org/10.1590/S0100-72032008000200008

[5] Sheffield, J.S. and Cunningham, F.G. (2005) Urinary Tract Infection in Women. Obstetrics and Gynecology, 106, 1085-1092. https://doi.org/10.1097/01.AOG.0000185257.52328.a2

[6] Joseph DiPiro, R.T., et al. (2011) Pharmacotherapy: A Pathophysiologic Approach. 
McGraw-Hill Medical, New York.

[7] Cheesbrough, M. (2005) District Laboratory Practice in Tropical Countries Part 2. Cambridge University Press, Cambridge, 1-266.

https://doi.org/10.1017/CBO9780511543470.002

[8] Cockerill, W.A., Dudley, E.F., Hardy, H.H., Patel, P.S., Thomson, T., Weinstein, Z., Franklin, R., Matthew, A., Jeff Michael, N., George, M., Mary Jane Dwight, J., David, W., Janet, A., Jean, B., Mair Jana, M., Richard, B., Maria, M., John, D., Melvin, P. and Barbara, L. (2012) Methods for Dilution Antimicrobial Susceptibility Tests for Bacteria That Grow Aerobically; Approved Standard. 12.1-56238-784-7.

[9] De Vaus, D. (2013) Surveys in Social Research. 6th Edition, Routledge, London, 41-121. https://doi.org/10.4324/9780203519196

[10] Amiri, M., Lavasani, Z., Norouzirad, R., Najibpour, R., Mohamadpour, M., Nikpoor, A.R., Raeisi, M. and ZareMarzouni, H. (2015) Prevalence of Urinary Tract Infection among Pregnant Women and Its Complications in Their Newborns during the Birth in the Hospitals of Dezful City, Iran, 2012-2013. Iranian Red Crescent Medical Journal, 17, e26946. https://doi.org/10.5812/ircmj.26946

[11] Onoh, R.C., Umeora, O.U.J., Egwuatu, V.E., Ezeonu, P.O. and Onoh, T.J.P. (2013). Antibiotic Sensitivity Pattern of Uropathogens from Pregnant Women with Urinary Tract Infections in Abakaliki, Nigeria. Journal of Infection Drug Resistant, 6, 225-233. https://doi.org/10.2147/IDR.S46002

[12] Jido, T.A., Nwankwo, E.O.K. and Magaji, N. (2006) Preliminary Microbiological Examination in Pregnant Women with Suspected Urinary Tract Infection in Kano, Nigeria. Nigerian Journal of Basic and Clinical Sciences, No. 1-2, 1-4.

[13] Onuh, S.O., Umeora, O.U.J., Igbarese, H.O., Aziken, M.E. and Okpere, E.E. (2006) Microbiologic Isolates and Their Sensitivity Pattern of Urinary Tract Infection in Pregnancy in Binin City, Nigeria. Ebonyi Medical Journal, 5, 48-52. https://doi.org/10.4314/ebomed.v5i2.41543

[14] Stephen, D.M. (2007) American Academy of Pediatrics and American College of Obstetricians and Gynecology. Guidelines for Perinatal Care. 6th Edition, American Academy of Pediatrics, Itasca, 207.

[15] Azami, M., Jaafariz, Z., Masoumi, M., Shohani, M., Badfar, G., Mahmudi, L. and Abbasalizadeh, S. (2019) The Etiology and Prevalence of Urinary Tract Infection and Asymptomatic Bacteriuria in Pregnant Women in Iran: A Systematic Review and Meta-Analysis. BMC Urology, 19, 43.

https://doi.org/10.1186/s12894-019-0454-8

[16] Kawser, P., Afroza, M., Arzumath, A.B. and Monowara, B. (2011) Prevalence of Urinary Tract Infection during Pregnancy. Journal of Dhaka National Medical Collection of Hospital, 7, 8-12. https://doi.org/10.3329/jdnmch.v17i2.12200

[17] Nwachukwu, E., Onyebuchi, O. and Michael, O. (2018) Prevalence of Urinary Tract Infections in Pregnant Women in Onitsha, Nigeria. Journal of Bacteriology and Mycology, 6, 284-285. https://doi.org/10.15406/jbmoa.2018.06.00219

[18] Ranjan, A., Tirumala, S., Sridhar, K., Matta, N., Chokkakula, S. and Ansari, R.K. (2018) Prevalence of UTI among Pregnant Women and Its Complications in Newborns. Indian Journal of Pharmacy Practice, 10, 45-49. https://doi.org/10.5530/ijopp.10.1.10

[19] Fasalu, O.M., Balasubramanian, T., Shejina, M. and Mohthash, M. (2015) A Review on Urinary Tract Infection in Pregnancy. International Journal of Pharma Research \& Review, 4, 26-33.

[20] Muhammad, A. and Muhammad, S.A. (2019) Prevalence of Urinary Tract Infection 
among Pregnant Women in Kano, Northern Nigeria. Archives of Reproductive Medicine and Sexual Health, 2, 23-29.

[21] Mohammad, N.A. (2013) Study of Frequency and Some Risk Factors of Urinary Tract Infection among Pregnant Women Attending El Sadat Family Health Unit in Suez Governorate. Unpublished M.Sc. Thesis, Zagazig University Faculty of Medicine, Zagazig.

[22] Dimetry, S.R., El-Tokhy, H.M., Abdo, N.M., Ebrahim, M.A. and Eissa, M. (2007) Urinary Tract Infection and Adverse Outcome of Pregnancy. The Journal of the Egyptian Public Health Association, 82, 203-218.

[23] Muhammed, M. (2014) Urinary Tract Infections amongst Pregnant Women Attending a Medical Centre in Kaduna, Nigeria. African Journal of Clinical and Experimental Microbiology, 16, 7-11. https://doi.org/10.4314/ajcem.v16i1.2 


\section{Appendix}

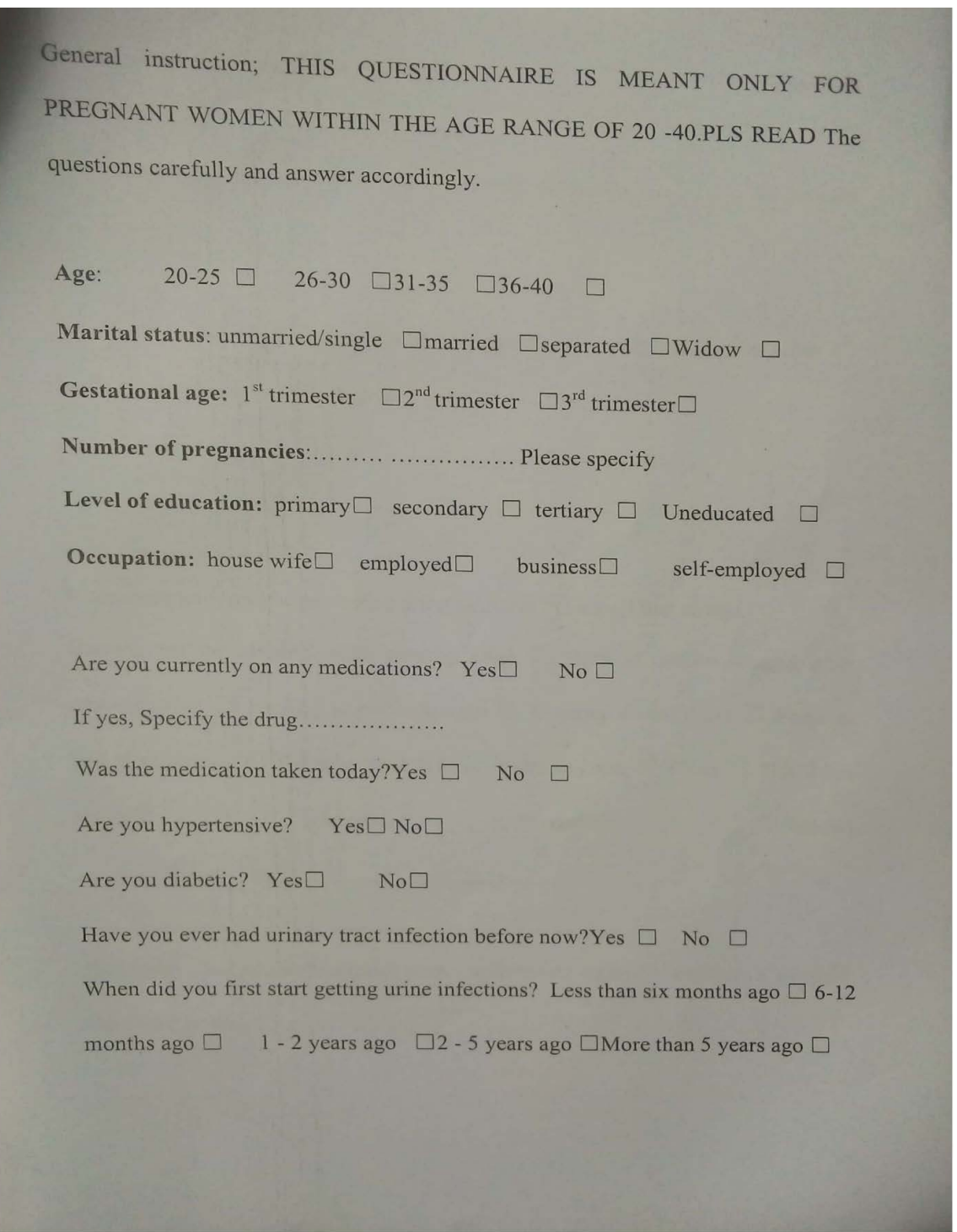

Scanned with Camscanner 


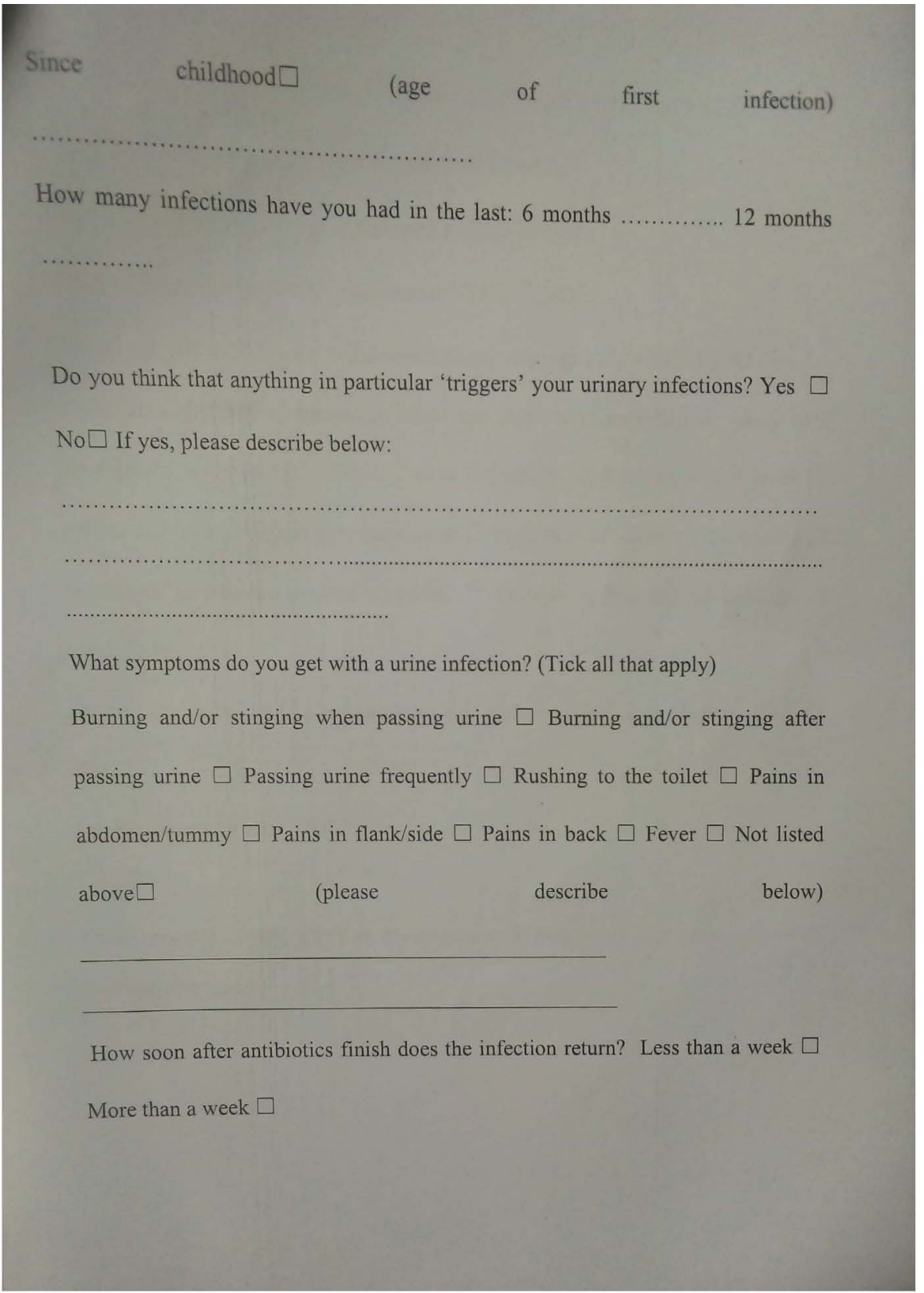

Scanned with Camsceanner 
Are your urine infections usually brought on by sexual intercourse? YES $\square$ NO $\square$

Have you ever passed air in your urine? YES $\square$ NO $\square$

Have you ever passed blood in your urine? YES $\square$ NO $\square$

Do you have problems with constipation? YES $\square$ NO $\square$

Do you use HRD (hormone replacement drugs) in pregnancy ? YES $\square$ NO $\square$

If you have any urinary symptoms when you don't have an Infection, please tick the relevant boxes below: Passing urine frequently $\square$ Rushing to the toilet $\square$ Abdominal pain $\square$ Straining to pass water $\square$ Poor flow of urine or slow stream $\square$ Feeling of incomplete bladder emptying $\square$ Burning or stinging $\square$ Leakage of urine $\square$ Fever $\square$

Do you use feminine hygiene products e.g. perfumed sprays or Vagisil? YES $\square$ NO $\square$

Do you smoke? YES $\square$ NO $\square$

Thank you for completing this questionnaire. Please bring this questionnaire to your appointment. 